Vol. 1 No. 2, Juli 2021, hlm. 95 - 102

DOI: https://doi.org/10.33330/j-com.v2i1.1206

Available online at http:// jurnal.stmikroyal.ac.id/index.php/j-com

\title{
PERANCANGAN SISTEM KEAMANAN FILE TRANSFER PROTOCOL DENGAN SECURE SOCKET LAYER PADA SERVER CENTOS 7
}

\author{
Alexander Theo Philus Tambunan ${ }^{1}$, Adi Prijuna Lubis ${ }^{2^{*}}$, Syartika Anggraini ${ }^{3}$ \\ 1 Mahasiswa Prodi Sistem Komputer, STMIK Royal \\ Prodi Sistem Komputer, STMIK Royal \\ *email:pri7n4@gmail.com
}

\begin{abstract}
An advancement in communication technology currently has an influence on developments in data management in the joints of life, making the need for a media center something a must in digital archive storage. Data will not always be stored in personal computers, but it would be better if there was a centralized data container to be a solution in storage media, in order to prevent data loss or data backup. The term network (network) is used when there are at least two or more devices that are connected to one another. To carry out data exchange in this network, a protocol is used that specifies how data is exchanged, and one of the most widely used protocols is the File Transfer Protocol (FTP). FTP is generally useful as a means of exchanging files or data in a network. The FTP protocol is not secure enough, because when data transfer there is no security to protect it. Therefore the FTP protocol is necessary for additional security, by implementing the SSL security protocol or Secure Socket Layer Security protecting the FTP protocol during data transfer. SSL certificates are used for the purpose of handling the security of data packets transmitted over the network system. When SSL is activated, the server and client when the connection occurs will be encrypted so that the data cannot be seen by others.
\end{abstract}

Keywords: FTP; Network; Server; SSL

\begin{abstract}
Abstrak: Suatu Kemajuan teknologi komunikasi saat ini memiliki pengaruh terhadap perkembangan didalam pengelolaan data didalam sendi kehidupan, membuat kebutuhan akan media center menjadi sesuatu yang harus dalam penyimpanan arsip digital. Data tidak selamanya akan tersimpan di dalam personal computer saja tetapi akan lebih baik jika ada wadah data terpusat menjadi solusi dalam media penyimpanan, agar menjaga dari kehilangan data atau cadangan data. Istilah jaringan (network) dipakai apabila terdapat minimal dua atau lebih perangkat yang terhubungkan satu dengan yang lainnya. Untuk melaksanakn pertukaran data didalam jaringan ini, digunakan protocol yang menspesifikasikan bagaimana data dipertukarkan, dan salah satu protocol yang banyak digunakan adalah File Transfer Protocol (FTP). FTP umumnya bermanfaat sebagai sarana pertukaran file atau data dalam suatu network. Protokol FTP tidaklah cukup aman, dikarenakan ketika transfer data tidak ada keamanan untuk melindunginya. Maka dari itu protokol FTP perlu untuk penambahan keamanan, dengan menerapkan protokol keamanan SSL atau Secure Socket Layer Security melindungi protokol FTP pada saat transfer data. Sertifikat SSL dimanfaatkan untuk keperluan menangani keamanan paket data yang ditransmisikan melalui sistem jaringan. Ketika SSL diakatifkan, maka server dan client ketika terjadi koneksi akan ter enkripsi sehingga data yang ada tidak dapat untuk dilihat oleh orang lain.
\end{abstract}

Kata kunci: FTP;Network; Server;SSL 
Vol. 1 No. 2, Juli 2021, hlm. 95 - 102

DOI: https://doi.org/10.33330/j-com.v2i1.1206

Available online at http:// jurnal.stmikroyal.ac.id/index.php/j-com

\section{PENDAHULUAN}

Suatu Kemajuan teknologi komunikasi saat ini memiliki pengaruh terhadap perkembangan didalam pengelolaan data. Dimana data dari satu lokasi bisa ditransfer ke lokasi lainnya menggunakan bantuan sarana telekomunikasi. Pengiriman data lewat komputer dilaksanakan melalui media transmisi elektronik, yang sering diartikan dengan pengistilahan komunikasi data (data communication). Istilah jaringan (network) dipakai apabila terdapat minimal dua atau lebih perangkat yang terhubungkan satu dengan yang lainnya. Untuk melaksanakn pertukaran data didalam jaringan ini, digunakan protocol yang menspesifikasikan bagaimana data dipertukarkan, dan salah satu protocol yang banyak digunakan adalah File Transfer Protocol (FTP).

FTP dasarnya berguna sebagai protocol guna sarana tukar menukar files atau data didalam suatu networks yang berbasiskan koneksi TCP. FTP merupakan protocol pilihan yang paling cocok digunakan dalam save files secara cepat dan efisien dalam proses uploads dan downloads dari komputer server ke client maupun sebaliknya [1]. FTP akan dapat diakses kapan saja selama user dapat terhubung dengan jaringan lokal maupun jaringan internet. Saat ini FTP menjadi rentan terhadap serangan cyber seperti Sniffing attack, Scanning, Man In The Midle Attack, DDoS dan lainnya [2]. Seranganserangan tersebut biasanya dilakukan untuk mengetahui username, password, maupun file yang di-upload atau yang di-download oleh user. Maka dari itu dibutuhkan layanan keamanan guna menjaga komunikasi antara user dengan server. FTP server dapat dibekali oleh Secure Socket Layer (SSL) [1]. SSL dirancang untuk memberikan jaminan keamanan dan layanan kompresi ke data yang dihasilkan dari lapisan aplikasi, ini biasanya ditemukan di HTTP, sebagai keamanan data antara transport dan aplication layer [3].

Teknologi Secure Socket Layer menggunakan konsep kriptografi kunci publik untuk bisa mencapai komunikasi yang benar-benar aman antara server dan client [4]. Kedua pihak yang berkomunikasi (server dan client) harus saling mengirimkan data yang disamarkan dengan teknik enkripsi, dan untuk membaca data tersebut digunakan kunci yang hanya dimiliki oleh kedua pihak yang sedang berkomunikasi saja. Sehingga apabila ada pihak lain yang mencoba untuk menyadap, data tidak akan terbaca atau tersamarkan dalam karakter yang acak.

Pada Dinas Pendidikan Kabupaten Asahan telah dilengkapi dengan sistem jaringan yang memadai. Proses pertukaran data telah dilakukan dengan menggunakan sharing files antar komputer satu ke komputer lain dan juga terkadang masih menggunakan cara manual menggunakan flashdisk. Namun permasalahan saat ini pada Dinas Pendidikan Kabupaten Asahan belum tersedia sebuah server sebagai tempat penyimpanan utama dilengkapi dengan sistem keamanan yang baik. Dengan tidak dilengkapinya keamanan, pada server penyimpanan bagi user, transfer data yang reliable dan efisien maka, memungkin komputer dapat menyebarkan virus, rawan terjadinya sniffing, modification dan fabrication data.

Beberapa penelitian terdahulu telah banyak dilakukan berkaitan FTP maupun penelitian yang mengkaji penggunaan Secure Socket Layer (SSL) sebagai system keamanan didalam komunikasi jaringan, untuk menganalisa protocol Secure Socket Layer terhadap dua bentuk serangan yaitu Heartbleed Bug dan Distributed Denial of Service (DDoS), [5], [6]. perancangan dan implementasi data center menggunakan FTP, 
Vol. 1 No. 2, Juli 2021, hlm. 95 - 102

DOI: https://doi.org/10.33330/j-com.v2i1.1206

Available online at http:// jurnal.stmikroyal.ac.id/index.php/j-com

diman data center yang dibangun pada penelitian tersebut adalah data center pada server mikrotik. [4]. merancang FTP dengan pengamanan open ssl pada jaringan VPN Mikrotik. [7] melakukan penelitian implementasi firewall dan port knocking untuk keamanan data pada FTP server yang berbasis linux ubuntu server.

Penggunaan metode FTP ini diharapkan dapat membantu mempermudah didalam penyimpanan files dan untuk berbagi data didalam jaringan. Selain itu penggunaan metode pengamanan dengan Secure Socket Layer bertujuan sebagai keamanan agar layanan yang ada menjadi aman dari penyadapan atau sniffing packet.

\section{METODE}

Dalam tahap perencanaan dilakukan pengumpulan data dan mempelajari landasan-landasan yang akan dibangun. Pengumpulan dilakukan berdasarkan pada studi pustaka yaitu mempelajari teori yang berkaitan dengan FTP server dan Secure Socket Layer (SSL).

Pada tahap analisis dilakukan pengidentifikasian terhadap kebutuhan penelitian. Hal ini diperlukan untuk menjadi acuan sistem yang dibangun. Kegiatan yang dilakukan dalam menganalisis yaitu memahami alur penyampaian informasi yang sedang berjalan, mengidentifikasi masalah yang terjadi pada sistem yang berjalan, dan mencari kesimpulan dari proses analisis yang telah dilakukan.

Sebuah kegiatan merancang server FTP dengan melakukan instalasi dan konfigurasi kemudian server FTP selesai di konfigurasi maka selanjutnya akan dilakukan perancangan terhadap sistem keamanan pada server tersebut. Aplikasi yang digunakan untuk melihat proses yang terjadi pada komunikasi yang berjalan adalah wireshark. Aplikasi ini dapat melihat packet header yang tercapture ketika komunikasi antara client dan server sedang berlangsung.

Uji coba sistem yaitu proses yang dilakukan untuk menilai apakah sistem yang dibuat telah sesuai dengan apa yang diharapkan, merupakan suatu kegiatan guna mengevaluasi keunggulan dan kelemahan terhadap sistem. Setelah sistem dibangun berdasarkan apa yang dirancang oleh penulis, maka penulis melakukan uji coba untuk mengevaluasi keunggulan dan kelemahan dari sistem yang telah dibangun. Ujicoba akan dilakukan dalam dua tahap dimana tahap pertama pengujian akan dilakukan pada FTP Server pada kondisi belum memiliki sistem keamanan, disini akan diuji dengan cara FTP server akan dicoba untuk di capture packet pada saat komunikasi antara server dan client. Kemudian pengujian kedua adalah saat FTP server telah dipasang Secure Socket Layer (SSL) pada pengujian kedua ini akan terlihat dampak dari penerapan sistem keamanan pada FTP server dibanding dengan kondisi sebelumnya.

Pada tahap ini merupakan proses akhir yaitu menganalisa dan evaluasi hasil pengujian sebelumnya dalam proses ini dilakukan evaluasi dan kesimpulan terhadap kualitas sistem yang telah dibangun.

\section{HASIL DAN PEMBAHASAN}

Dengan melihat permasalahan yang terjadi di Sistem Jaringan dinas pendidikan 
Vol. 1 No. 2, Juli 2021, hlm. 95 - 102

DOI: https://doi.org/10.33330/j-com.v2i1.1206

Available online at http:// jurnal.stmikroyal.ac.id/index.php/j-com

kabupaten asahan maka peneliti mengusulkan untuk membangun Server FTP yang akan mengatasi pertukaran data menggunakan perangkat eksternal, menyediakan keamanan data dan menyediakan tempat penyimpanan data yang reliable dan efisien serta memiliki sistem keamanan yang baik. Dari sistem jaringan yang berjalan pada dinas pendidikan peneliti tetap menggunakan alokasi IP Address yang sedang berjalan hanya menambahkan IPAddress static pada router untuk dipergunakan oleh Server FTP Adapun topologi dari sistem yang di usulkan tertera pada Gambar 1 berikut ini.

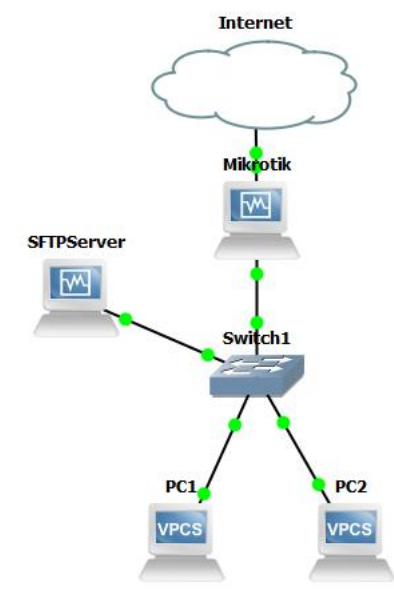

Gambar 1. Topologi Usulan

Implementasi sistem keamanan FTP dengan Secure Socket Layer akan diaplikasikan pada CentOS 7 server. Dalam pengujian ini sistem ini diimplementasikan dalam bentuk virtualisasi menggunakan Virtual Box yang dapat dijalankan diberbagai platform sistem operasi seperti Windows, Linux maupun Mac OS. Pengujian ini dilakukan menggunakan laptop untuk menjalankan virtualisasi CentOS Server yang telah dikonfigurasi sebagai Domain Server, FTP dan juga dilengkapi protocol Secure Socket Layer.

Pada sistem yang dibangun akan dilakukan beberapa pengujian, ini dilakukan agar sistem yang dibuat dapat berjalan sesuai dengan kebutuhan dan tujuan dalam jurnal ini. Rangkaian pengujian yang dilakukan adalah pengujian domain server, pengujian FTP Server dan pengujian keamanan FTP Server.

Domain Name Server atau biasa juga disingkat penyebutannya dengan DNS merupakan suatu layanan pada server yang berfungsi untuk mempermudah seorang user atau pengguna didalam mengakses suatu layanan seperti FTP Server maupun Web server. Fungsi utama dari DNS server sebagai penerjemah IPAddress kedalam bentuk kata yang unik maupun dari kata unik kedalam bentuk IPAddress. Dalam sistem yang telah dibuat alamat domain name yang dibuat adalah ftp.disdik.asahankab.go.id. Alamat domain ini nantinya dapat diakses secara local oleh user untuk menggunakan layanan FTP Server yang tersedia. Untuk pengujian domain name ini dapat dilakukan dengan beberapa cara, salah satunya dengan perintah ping ftp.disdik.asahankab.go.id melalui command prompt pada windows atau terminal pada linux. Selain dengan cara tersebut dapat juga dilakukan dengan cara lainnya yaitu dengan menggunakan perintah dig ftp.disdik.asahankab.go.id seperti yang terlihat pada gambar 2 berikut ini. 
Vol. 1 No. 2, Juli 2021, hlm. 95 - 102

DOI: https://doi.org/10.33330/j-com.v2i1.1206

Available online at http:// jurnal.stmikroyal.ac.id/index.php/j-com

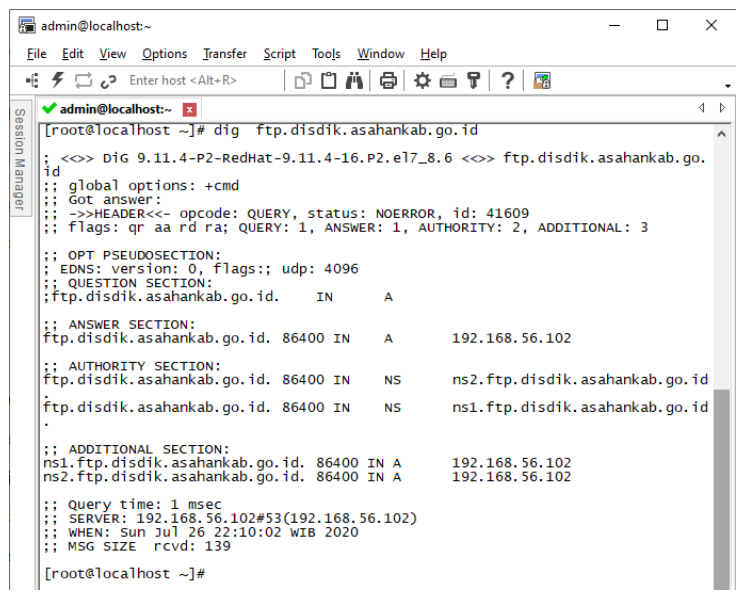

Gambar 2. Uji Coba Domain Server

Pada gambar 2 merupakan uji coba terhadap Domain Name Server dengan menggunakan perintah dig ftp.disdik.asahankab.go.id. Perintah dig merupakan perintah command line pada linux yang sangat baik. Dengan menggunakan perintah dig maka dimungkinkan untuk mengecek record Domain Name Server (DNS) seperti IPAddress Domain, A record dan lain sebagainya. Berdasarkan pengujian yang dilakukan pada tahap ini telah menunjukkan bahwa konfigurasi untuk Domain Name Server telah berhasil dan dapat digunakan.

Pengujian akses FTP server dilakukan dengan menggunakan aplikasi khusus yaitu file zilla, dengan aplikasi ini user dapat dengan mudah untuk mengambil atau mendownload file yang ada pada server, sesuai dengan kebutuhan yang diinginkan. Disini user yang mengakses FTP server akan diminta untuk memasukkan password terlebih dahulu, guna keamanan akses pada FTP server. Setelah user berhasil login maka user dapat menggunakan FTP server untuk beberapa keperluan pengambilan data dari server maupun menyimpan data ke server. Pada gambar 3 disini akan dilakukan uji coba untuk mengambil data dari server dengan cara mendownload data yang terdapat pada salah satu directory penyimpanan pada server.

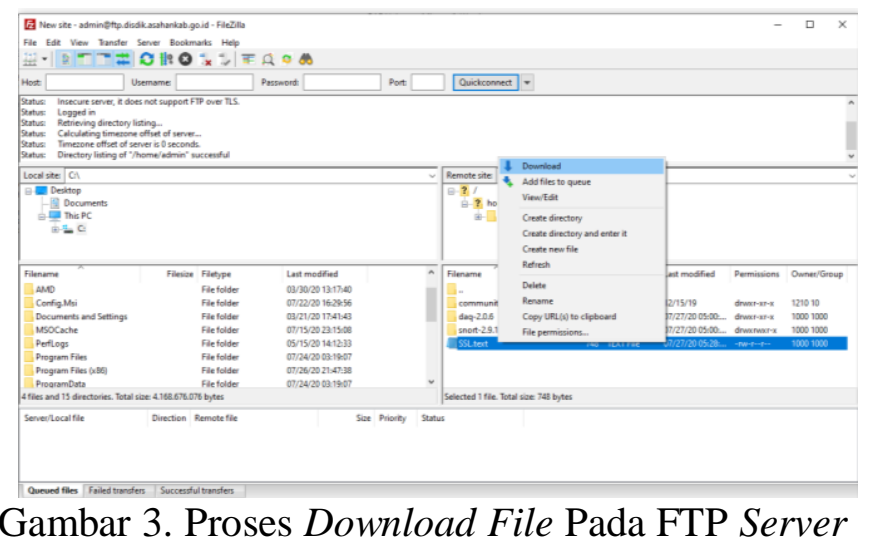

Selain untuk men-download file atau dokumen pada server layanan FTP juga menyediakan fasilitas upload, sehingga user juga dapat menyimpan data atau dokumennya pada FTP server. Untuk layanan FTP server telah berjalan dengan baik 
Vol. 1 No. 2, Juli 2021, hlm. 95 - 102

DOI: https://doi.org/10.33330/j-com.v2i1.1206

Available online at http:// jurnal.stmikroyal.ac.id/index.php/j-com

maka selanjutnya perlu dilakukan uji coba terhadap kemanan dari layanan FTP server ini. Untuk menguji keamanan suatu server disini penulis mekukakan pembacan paket yang lewat didalam jaringan atau teknik ini juga biasa disebut dengan sniffing. Dengan teknik ini akan didapatkan sekumpulan proses komunikasi yang terjadi yaitu proses komunikasi didalam jaringan. Selanjutnya dari hasil tangkapan data tersebut dapat dilihat apakah komunikasi yang terjadi aman atau tidak. Misalnya ketika user login ke server FTP user dan passwordnya serta aktivitas yang dikerjakan dapat atau tidak dibaca oleh pihak ketiga.

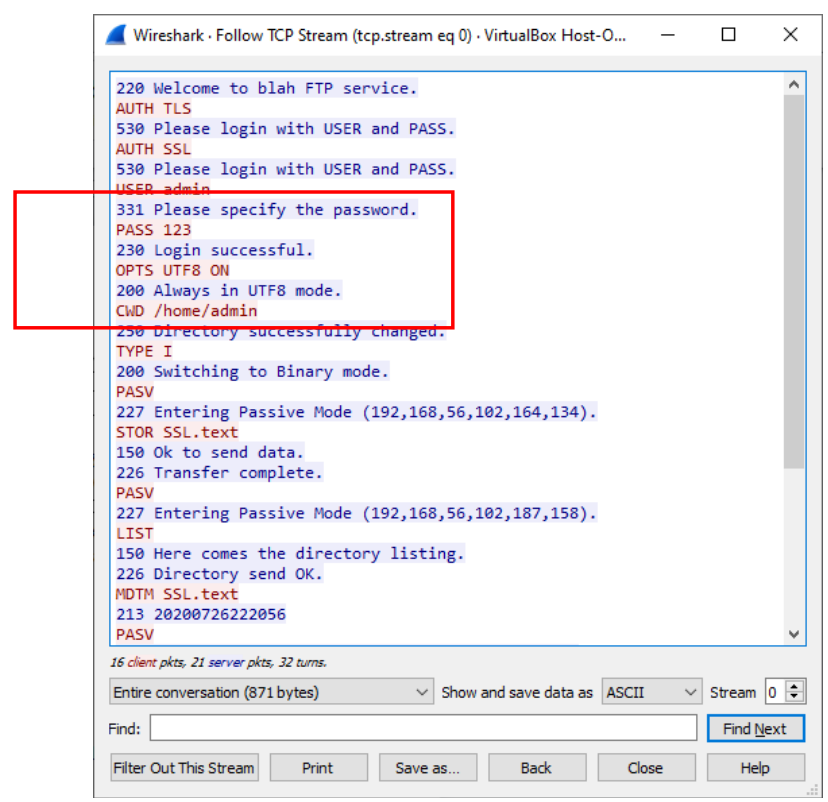

Gambar 4. Hasil Pengujian Awal Keamanan FTP Server

Pada gambar 4 dapat dilihat hasil capturing packet dengan wireshark pada FTP server, dimana dapaat dilihat sebuah fakta bahwa FTP server yang tidak dilengkapi dengan keamanan SSL dapat dilihat packet data yang di trasmisikan. Pada hasil capturing packet tersebut diperoleh hasil yaitu mendapatkan user dan passsword untuk admin FTP server. Ini terjadi dikarenakan komunikasi antara server dengan client tidak di enkripsi sehingga dengan dilakukan penyerangan dengan teknik sniffing paket data yang dikomunikasikan tersebut dapat dilihat. Pada tahapan ini server FTP sudah siap digunakan namun dalam komunikasinya belum aman sepenuhnya.

Pada layanan FTP server yang dibangun ini menggunakan sistem keamanan dengan menggunakan kriptografi algoritma RSA 2048 dalam bentuk certifikat Secure Socket Layer (SSL) yang dipasang pada server. Untuk pertama kali akses ke server FTP maka akan muncul satu form notifikasi yang menunjukkan terdapat certifikate yang tidak dikenal. disini setiap user yang menggunakan filezilla harus mendaftarkan certificate tersebut ke aplikasi yang digunakan agar layanan FTP servernya dapat digunakan dengan baik. setelah verifikasi certificate tersebut selesai barulah user dapat menggunakan layanan FTP Server.

Selanjutnya disini perlu diuji Kembali untuk tingkat keamanan dari FTP Server. Sebelumnya telah dilakukan penyadapan atau serangan packet sniffing ke FTP Server dari awal yaitu saat pertama login user login ke FTP server. Pada gambar 5 
Vol. 1 No. 2, Juli 2021, hlm. 95 - 102

DOI: https://doi.org/10.33330/j-com.v2i1.1206

Available online at http:// jurnal.stmikroyal.ac.id/index.php/j-com

disini memperlihatkan hasil dari serangan packet sniffing dimana setiap data yang dikomunikasikan di FTP Server sudah di enkripsi sehingga data tidak lagi dapat disadap, di modification dan fabrication [9].

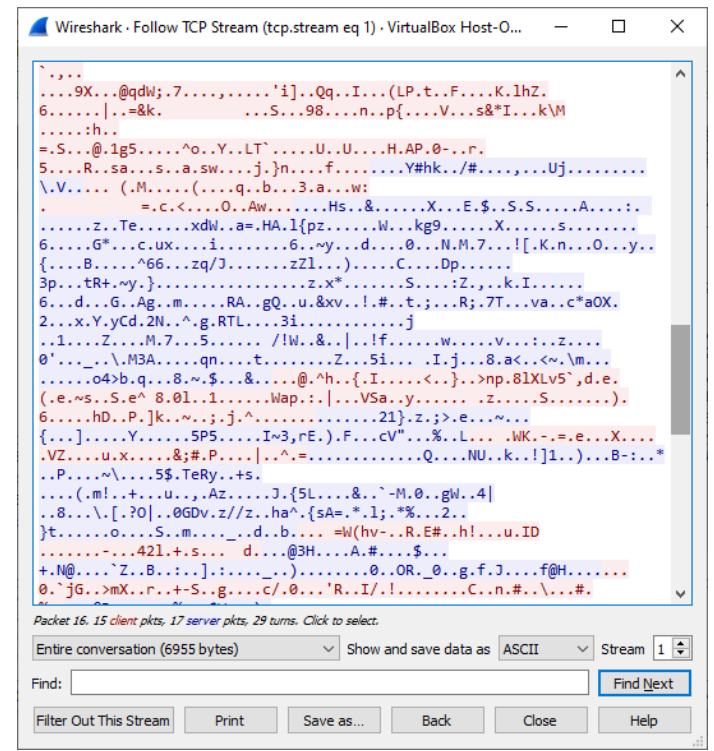

Gambar 5. Hasil Pengujian Keamanan FTP Server

\section{SIMPULAN}

Dari serangkaian penelitian dan hasil uji coba maka disini dapat disimpulkan bahwa Metode pengamanan dengan Secure Socket Layer (SSL) dapat di implementasikan dan berjalan dengan baik pada FTP Server. Keamanan File Transfer Protocol (FTP) dengan menggunakan Secure Socket Layer (SSL) secara standar terbukti dapat melindungi transmisi FTP Server dari Tindakan penyadapan paket data.

\section{DAFTAR PUSTAKA}

[1] D. Ruwaida and D. Kurnia, "Rancang Bangun File Transfer Protocol (Ftp) Dengan Pengamanan Open Ssl Pada Jaringan Vpn Mikrotik Di Smk Dwiwarna," Comput. Eng. Sci. Syst. J., vol. 3, no. 1, p. 45, 2018, doi: 10.24114/cess.v3i1.8267.

[2] Khairunnisa and Sutarti, "Perancangan Dan Analisis Keamanan Jaringan Nirkabel Dari Serangan Ddos ( Distributed Denial of Service ) Berbasis Honeypot," J. PROSISKO, vol. 4, no. 2, p. 8, 2017.

[3] J. A. Habibi, R. Munadi, and L. V. Yovita, "Analysis secure socket layer protocol with heartbleed bug and distributed denial-of-service," ICCEREC 2016 - Int. Conf. Control. Electron. Renew. Energy, Commun. 2016, Conf. Proc., pp. 54-59, 2017, doi: 10.1109/ICCEREC.2016.7814960.

[4] N. Novi and Z. Zaini, "Secure Socket Layer untuk Keamanan Data Rekam Medis Tumor Otak pada Health Information System," J. Nas. Tek. Elektro, vol. 6, no. 3, 
Vol. 1 No. 2, Juli 2021, hlm. 95 - 102

DOI: https://doi.org/10.33330/j-com.v2i1.1206

Available online at http:// jurnal.stmikroyal.ac.id/index.php/j-com

p. 137, 2017, doi: 10.25077/jnte.v6n3.405.2017.

[5] D. Q. Shengrong Mao, "Design and Implementation of An Embedded FTP Server Powered over Ethernet Shengrong Mao, Donghai Qiao,” pp. 2421-2424, 2016.

[6] B. Kurniawan and D. Herryanto, "Perancangan Dan Implementasi Data Center Menggunakan File Transfer Protocol (Ftp)," Peranc. Dan Implementasi Data Cent. Menggunakan File Transf. Protoc., vol. 2, no. 2, pp. 91-97, 2017, doi: 10.1360/zd-2013-43-6-1064.

[7] S. Khadafi, S. Nurmuslimah, and F. K. Anggakusuma, "Implementasi Firewall Dan Port Knocking Sebagai Keamanan Data Transfer Pada Ftp Server," vol. 4, no. 3, pp. 181-188, 2019.

[8] A. R. Adiguna, M. Saputra Chandra, and F. Pradana, "Analisis dan Perancangan Sistem Informasi Manajemen Gudang pada PT Mitra Pinasthika Mulia Surabaya," Pengantar Sist. Inf., vol. 2, no. 2, pp. 612-621, 2018, doi: 10.1016/j.humimm.2008.04.008.

[9] S. Prabhakar, "Research in Computer Applications and Robotics Network Security in Digitalization : Attacks and," vol. 5, no. 5, pp. 46-52, 2017. 